\title{
Methane- and ammonia-oxidizing bacteria at the chemocline of Lake Kinneret (Israel)
}

\author{
Pilar Junier ${ }^{1,2, *}$, Ok-Sun Kim ${ }^{2,3}$, Werner Eckert ${ }^{4}$, Peter Casper ${ }^{5}$, Johannes F. Imhoff ${ }^{6}$, \\ Karl-Paul Witzel ${ }^{2}$, Ora Hadas ${ }^{4}$ \\ ${ }^{1}$ Ecole Polytechnique Federale de Lausanne, Station 6, 1015 Lausanne, Switzerland \\ ${ }^{2}$ Max-Planck Institute for Evolutionary Biology, August-Thienemann-Str. 2, 24306 Plön, Germany \\ ${ }^{3}$ School of Biological Sciences and Institute of Microbiology, Seoul National University, 56-1 Shillim-dong, Kwanak-gu, \\ Seoul 151-742, ROK \\ ${ }^{4}$ Israel Oceanographic and Limnological Research, The Kinneret Limnological Laboratory, PO Box 447, 14950 Migdal, Israel \\ ${ }^{5}$ Leibniz-Institute of Freshwater Ecology and Inland Fisheries, Alte Fischerhütte 2, 16775 Stechlin, Germany \\ ${ }^{6}$ Leibniz-Institute of Marine Sciences at the University of Kiel, Düsternbrooker Weg 20, 24105 Kiel, Germany \\ ${ }^{7}$ Present address: Laboratory of Microbiology, University of Neuchâtel, Rue Emile-Argand 11, 2000 Neuchâtel, Switzerland
}

\begin{abstract}
The vertical distribution of methane- and ammonia-oxidizing bacteria (MOB and AOB, respectively), and the physicochemical conditions in the chemocline of Lake Kinneret (Israel) were studied at a resolution of $10 \mathrm{~cm}$ from 16.2 to $17.7 \mathrm{~m}$ depth. Profiles of the chemical parameters indicated decreasing concentrations of methane (from 22.4 to $0.11 \mu \mathrm{mol} \mathrm{l}^{-1}$ ) and ammonia (from 14.2 to $8.4 \mathrm{umol} \mathrm{l}^{-1}$ ) towards the water surface and in close proximity to the chemocline. The disappearance of methane coincided with methane oxidation that could be corroborated throughout this layer with highest rates at 17.4 to $17.6 \mathrm{~m}$. Disappearance of ammonia could not be linked to ammonia oxidation exclusively. The genes $p m o A$ and the homologous amoA (coding for subunit $\alpha$ of the methane and ammonia monooxygenase, respectively) were amplified by PCR. The products were analyzed by terminal restriction fragment length polymorphism (T-RFLP) and sequencing of clone libraries. The results demonstrated that different $\mathrm{MOB}$ and $\mathrm{AOB}$ communities are established along the concentration gradient within the narrow layer of the metalimnetic chemocline. Changes in the intensity of the T-RFLP peaks and the frequency of different groups of alpha- and gammaproteobacterial MOB, and betaproteobacterial AOB, coincided with the concentration gradients of methane, ammonia, nitrate, and oxygen in the chemocline. This suggests that different communities of MOB, and to a lesser extent $\mathrm{AOB}$, contribute to the formation of chemical gradients of their particular substrates in the chemocline.
\end{abstract}

KEY WORDS: $a m o A \cdot p m o A \cdot C h e m o c l i n e \cdot A m m o n i a \cdot M e t h a n e$

Resale or republication not permitted without written consent of the publisher

\section{INTRODUCTION}

The chemocline of thermally stratified lakes delineates the interface between oxic and anoxic conditions and as such is characterized by extremely sharp chemical gradients. While the location of the chemocline within the metalimnion is determined by physical forcing (i.e. the interplay between shear stress and buoyancy), the chemical gradients are influenced by microbial activity (Eckert \& Conrad 2007). Competition for the available energy sources and for suitable electron acceptors is expected to cause a distinct stratification of microbial communities within a very narrow zone. The oxic-anoxic interfaces are favorable for growth of microaerophilic, heterotrophic bacteria as well as chemosynthetic bacteria that gain metabolic energy by oxidation of reduced substances such as hydrogen, sulfide, or thiosulfate (Hadas et al. 2001).

Methane and ammonia are among the substrates amenable for oxidation. Methane and ammonia oxidation are thought to be most active at the interface between oxic and anoxic zones in freshwater lakes 
(Hanson \& Hanson 1996, Brune et al. 2000), where gradients of methane and ammonia meet those of oxygen. Methane-oxidizing bacteria (MOB) are unique in their ability to utilize methane as an energy source (Hanson \& Hanson 1996). Ammonia-oxidizing bacteria (AOB) are chemoautotrophic bacteria using ammonia as an electron donor and energy source for carbon dioxide fixation (Prosser 1990). The enzymes responsible for the substrate oxidation in both groups, the particulate methane monooxygenase (pMMO) in $\mathrm{MOB}$ and the ammonia monooxygenase (AMO) in $\mathrm{AOB}$, share a significant level of similarity in function and structure (Holmes et al. 1995, Semrau et al. 1995). Therefore, it has been possible to study both groups simultaneously with PCR primers designed to amplify fragments coding for the subunit containing the active site of $\mathrm{pMMO}$ and AMO (pmoA and $a m o A_{;}$Holmes et al. 1995).

The aims of this study were to evaluate whether environmental gradients along the chemocline affect the community structure of $\mathrm{MOB}$ and $\mathrm{AOB}$, and whether relationships exist between the structure of the specific microbial communities and the consumption of methane and ammonia in this layer. To accomplish these goals, the communities of MOB and AOB, as well as the concentrations of methane and ammonia, and methane oxidation rates were analyzed in a high-resolution depth profile within the metalimnetic layer of Lake Kinneret (Israel).

\section{MATERIALS AND METHODS}

Field site. Lake Kinneret is a monomictic subtropical freshwater lake, located in the northern part of Israel. The water column shows a distinct seasonal pattern of chemical stratification characterized by changes in the concentration of dissolved oxygen, ammonia, and sulfide. After turnover and during the mixing period (late December to March), the concentrations of oxygen and nitrate are high throughout the whole water column. With the onset of thermal stratification in April, oxygen is gradually depleted in the hypolimnion due to the quick degradation of the annual massive bloom of the dinoflagellate Peridinium gatunense. During stratification, an aerobic warm epilimnion $\left(18\right.$ to $\left.28^{\circ} \mathrm{C}\right)$ and an anoxic relatively cold hypolimnion $\left(14\right.$ to $\left.16^{\circ} \mathrm{C}\right)$ are formed (Eckert et al. 2002). In October, the thermocline and oxycline move deeper to below the photic zone, making photosynthetic primary production in the metalimnion impossible.

Sampling and measurements of chemical parameters. Water samples were collected at Stn A (maximum depth $42 \mathrm{~m})$, representing the pelagic area of the lake. The samples were collected in a depth profile between 16.2 and $17.7 \mathrm{~m}$ at intervals of $10 \mathrm{~cm}$ with a pneumatic, cus- tom-made syringe sampler. Biogeochemical and genetic analyses were made from the same subset of samples. In addition, a sample from the Jordan River immediately before the inflow into the lake was used as a reference for the community analysis. Methane concentration was measured according to the methods of Schmidt \& Conrad (1993) and Eckert \& Conrad (2007). Concentrations of ammonia, nitrate, and oxygen were measured according to standard methods (APHA 2001).

Methane oxidation rate. Using the same syringe sampler described above, another set of water samples was taken from the same depths, and $20 \mathrm{ml}$ of water from each depth were distributed into $60 \mathrm{ml}$ serum bottles. The headspace contained atmospheric oxygen concentrations, while methane was added to each flask at a final concentration of approximately $150 \mu \mathrm{mol} \mathrm{l}^{-1} \mathrm{CH}_{4}$ at the beginning of the experiment. The bottles were incubated in the dark at in situ temperatures $\left(26^{\circ} \mathrm{C}\right)$ for $140 \mathrm{~h}$, slightly shaken, and the decrease in methane concentration was measured every $24 \mathrm{~h}$ with a gas chromatograph (Shimadzu GC 8). Methane oxidation rates were calculated from the decrease in methane concentration over time.

DNA extraction and PCR. Samples (between 12 and $20 \mathrm{ml}$ ) were filtered onto $0.2 \mu \mathrm{m}$ pore size filters (Supor-200, PALL Life Sciences) and stored at $-18^{\circ} \mathrm{C}$ until DNA was extracted using the UltraClean Soil DNA kit (MoBio), following the manufacturer's guidelines. The amo $A$ and $p m o A$ genes were amplified simultaneously with the primers A189 and A682 (Holmes et al. 1995). To produce products for T-RFLP, the PCR was set up in a total volume of $25 \mu \mathrm{l}$ with $2.5 \mathrm{ng}$ DNA as template, $1 \times$ PCR buffer, $200 \mu \mathrm{M}$ of each dNTP, $200 \mathrm{nM}$ of each primer, $2.5 \mathrm{mM} \mathrm{MgCl}_{2}, 1 \%$ formamide, $0.1 \% \mathrm{BSA}$, and $1 \mathrm{U}$ of Taq polymerase. The amplification consisted of an initial denaturation at $94^{\circ} \mathrm{C}$ for $5 \mathrm{~min}$, followed by 35 cycles of $94^{\circ} \mathrm{C}$ for $1 \mathrm{~min}, 57^{\circ} \mathrm{C}$ for $1 \mathrm{~min}$, and $72^{\circ} \mathrm{C}$ for 1.5 min. PCR products for cloning were prepared under the same conditions but using the proofreading $P f u$ DNA polymerase (Promega).

Terminal restriction fragment length polymorphism (T-RFLP). The T-RFLP analysis was carried out as described in Junier et al. (2008c). Briefly, for T-RFLP the primer A189 was labeled with 5-carboxyfluorescein (FAM). From each sample, 3 independent PCR reactions were pooled, gel purified, quantified, and digested overnight at $37^{\circ} \mathrm{C}$ with $5 \mathrm{U}$ of either HaeIII, MspI, MboI, AluI, or TaqI (New England Biolabs). Restriction products were separated on an ABI3100 Automated Sequencer. Fragment size was estimated by comparison to the standard ROX-500 (Applied Biosystems). T-RFLP data were analyzed using GeneScan 3.1 software (Applied Biosystems). Data analysis was carried out as described in Junier et al. (2008c). Simulations of terminal restriction fragments (T-RFs) 
from clonal sequences from this study were carried out using TRiFLe (Junier et al. 2008a). Statistical analyses were carried out using the softwares Primer E (clustering and multidimensional scaling; Clarke 1993) and R (www.R-project.org).

Cloning and sequencing. Construction of clone libraries and sequencing were performed as described elsewhere (Kim et al. 2006). Sequences reported in this study were deposited in GenBank under the accession numbers FJ024342-FJ024348 for amoA and FJ024349FJ024404 for pmoA.

Sequence analysis. Phylogenetic analyses were carried out using the software ARB (www.arb-home.de) with a database containing all amoA/pmoA sequences from GenBank (Junier et al. 2008b). Phylogenetic trees were constructed from amino acid sequences with the PHYLIP subroutine in ARB using the neighbor-joining algorithm and a substitution matrix calculated with the Jones-Taylor-Thornton (JTT) model.

\section{RESULTS}

\section{Methane and ammonia concentration profiles and methane oxidation rates in the water column}

The metalimnion of Lake Kinneret was characterized by a sharp decline in oxygen, temperature, and redox potential (Fig. 1A). A closer look at the oxygen concentrations showed that they dropped considerably at water depths below $16.7 \mathrm{~m}$ and reached the detection limit between 17.0 and $17.6 \mathrm{~m}$ (Fig. 1B). Methane concentrations declined from 22.4 to $0.12 \mu$ mol $\mathrm{l}^{-1}$ at depths from 17.7 to $16.2 \mathrm{~m}$. Ammonia concentrations decreased less drastically from $14.2 \mu \mathrm{mol} \mathrm{l}^{-1}$ at $17.7 \mathrm{~m}$ to $8.4 \mu_{\mathrm{mol}} \mathrm{l}^{-1}$ at $16.2 \mathrm{~m}$. Nitrate was detectable only above $16.5 \mathrm{~m}$ depth (0.09 to $0.35 \mathrm{\mu mol}^{-1}$; Fig. $\left.1 \mathrm{C}\right)$. Oxidation rates of methane increased with depth, reaching a maximum of $0.8 \mu \mathrm{mol} \mathrm{l}^{-1} \mathrm{~h}^{-1}$ at $17.6 \mathrm{~m}$ (Fig. 1C), where high methane concentrations were measured, while oxygen concentrations were very low or not detectable (Fig. 1B).

\section{Changes in the community composition of MOB and AOB in the chemocline}

Using appropriate primers for simultaneously amplifying gene fragments of the subunit containing the active sites of pMMO and AMO and (pmoA and amoA), PCR products were obtained from samples at various depths of the profile.

T-RFLP analysis of the PCR products was made to analyze possible differences in the community structure of $\mathrm{MOB} / \mathrm{AOB}$ along the depth profile. Differences of the T-RFLP patterns along the depth profile were mainly
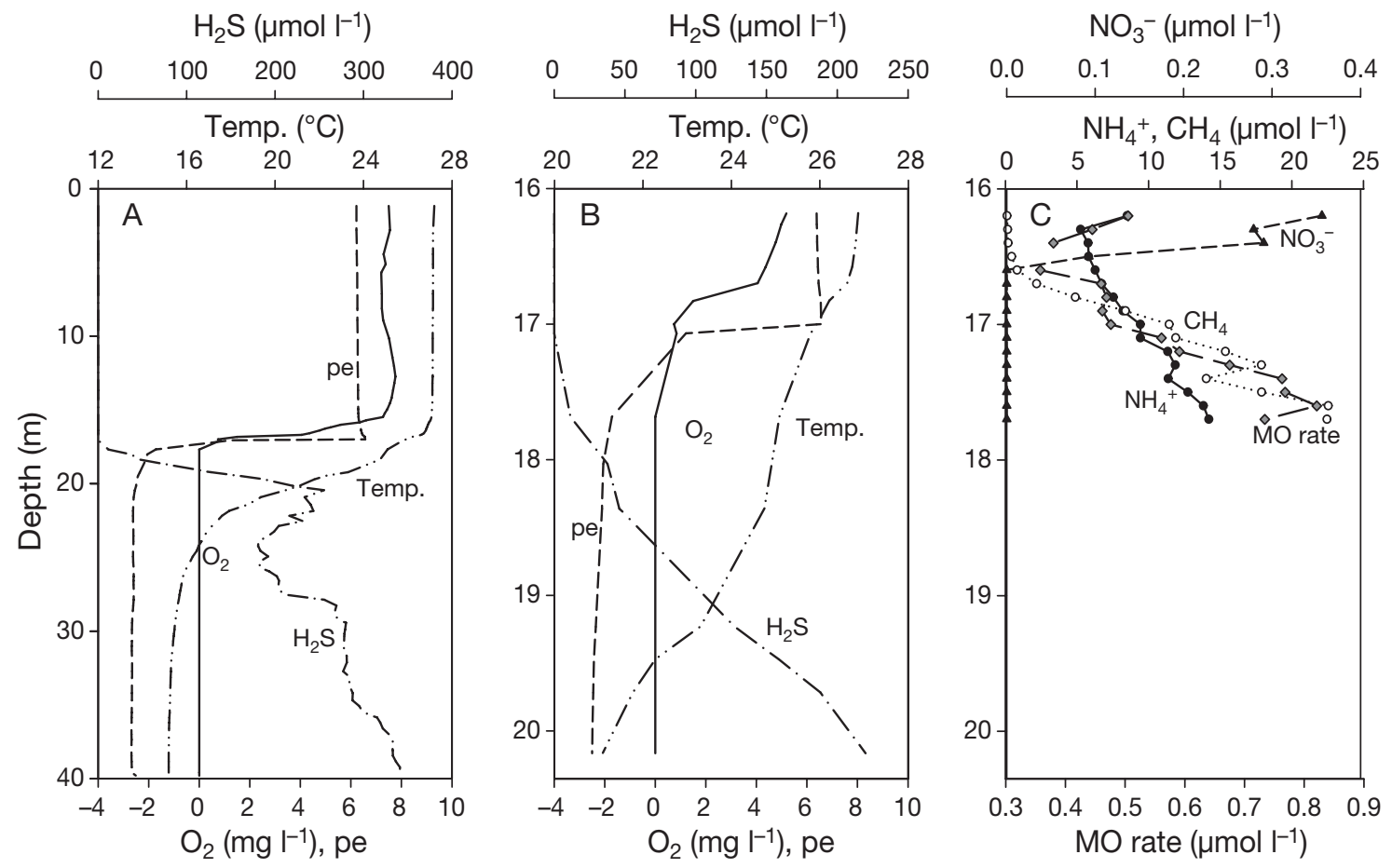

Fig. 1. Depth profiles taken at Stn A in Lake Kinneret, Israel. (A) General profile showing the changes in $\mathrm{H}_{2} \mathrm{~S}$, temperature, oxygen, and redox potential (pe) at the chemocline. (B) Close up of the same parameters measured at the chemocline. (C) Profiles of $\mathrm{NH}_{4}{ }^{+}, \mathrm{CH}_{4}$, and $\mathrm{NO}_{3}^{-}$, including methane oxidation rates profile analyzed in water samples from Stn $\mathrm{A}$ 


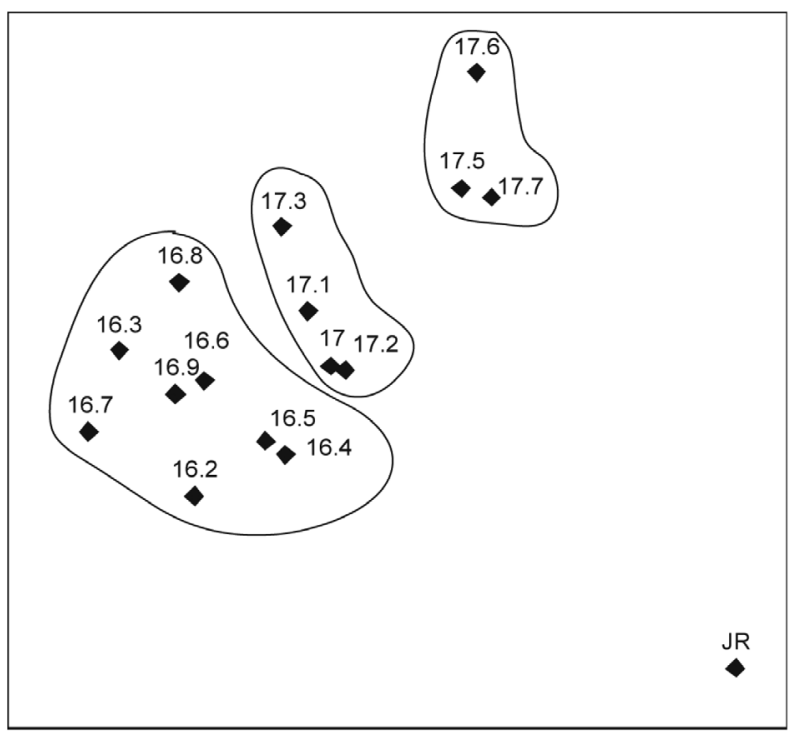

Fig. 2. Multidimensional scaling (MDS) analyses calculated using Prime v3.1 of terminal restriction fragment length polymorphism (T-RFLP) profiles (presence and relative abundance of peaks) of pmoA/amoA PCR products. The combination of the results for the individual digestions with HaeIII, MspI, MboI, TaqI, and AluI were used. Groups distinguished by the MDS are indicated. Numbers represent the different depths sampled. JR: sample from the Jordan River

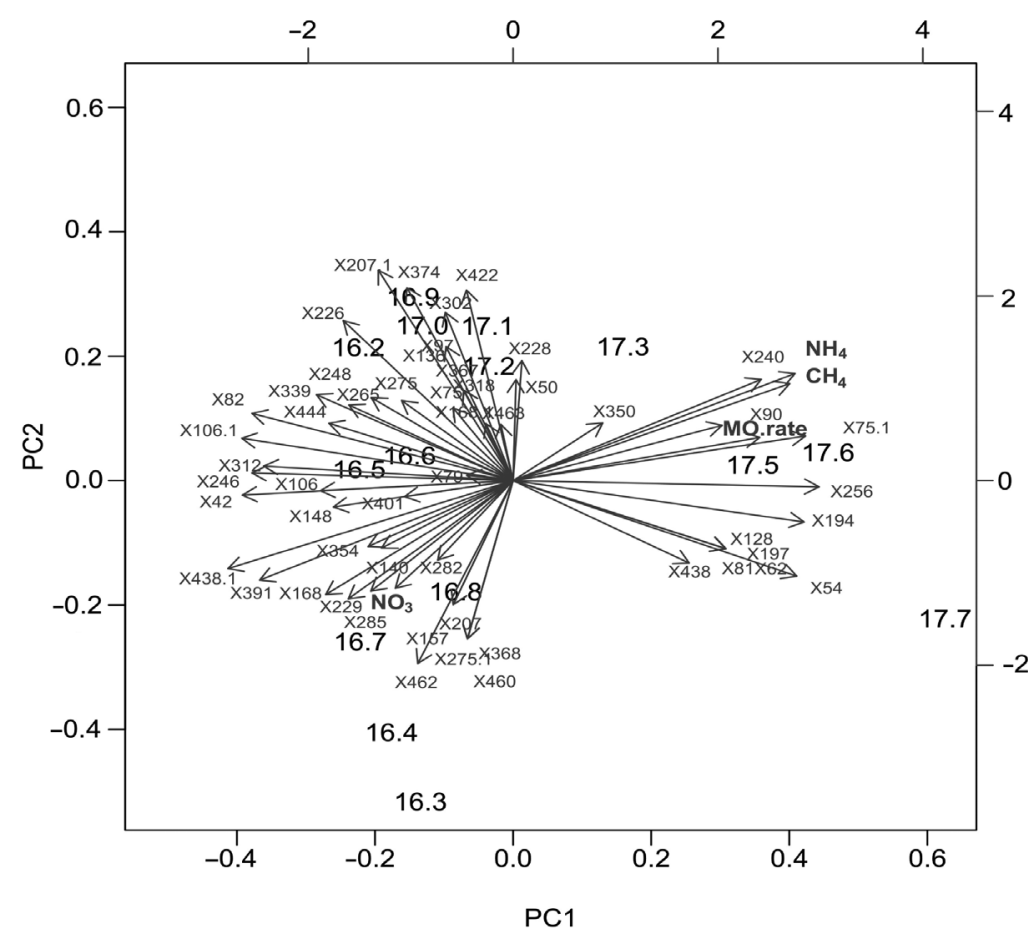

Fig. 3. Principal component analysis (PCA) using the terminal restriction fragment length polymorphism (T-RFLP) frequencies and the environmental data in the same matrix represented in a bi-plot graph. Data from the sample of the Jordan River were omitted from the matrix. Vectors from ammonia $\left(\mathrm{NH}_{4}\right)$, methane $\left(\mathrm{CH}_{4}\right)$, nitrate $\left(\mathrm{NO}_{3}\right)$ and methane oxidation rate (MO rate) are indicated in bold due to changes in the relative intensity of specific peaks common to all samples, rather than to the disappearance of some peaks or the appearance of new ones (Fig. S1, available as AME Supplementary Material at www.int-res.com/articles/suppl/a058p241_app.pdf). The combination of T-RFLP data after digestion with 5 different enzymes was analyzed by clustering and multidimensional scaling (MDS). Both analyses showed similar results, and therefore only MDS is presented. The pattern of T-RFs from the Jordan River was included in the analysis as an outgroup (Fig. 2). All communities from Lake Kinneret were clearly separated from those in the Jordan River. Within the lake, the communities could be divided into 3 groups: the first group contained samples from 16.2 to $16.9 \mathrm{~m}$, the second from 17.0 to $17.3 \mathrm{~m}$, and the third those from 17.5 to $17.7 \mathrm{~m}$ depth, the deepest part of the profile. The clear separation of this third group from the 2 others coincided with very low oxygen concentrations and with high methane oxidation rates.

Further analysis of the T-RFLP patterns from the lake samples was conducted to analyze their correlation with the environmental factors (methane, ammonia, nitrate, and methane oxidation rate). Methane, ammonia, and the rates of methane oxidation were correlated with the separation of the samples in the deeper part of the profile (17.5 to $17.7 \mathrm{~m}$ ) when a PCA analysis was conducted omitting the sample from the Jordan River (Fig. 3). In contrast, nitrate concentration was linked to the separation of samples from 16.3, 16.4, 16.7, and $16.8 \mathrm{~m}$. The contribution of individual peaks to the separation is not evident; rather, a combination of several peaks better explains the differentiation of the samples.

\section{Sequence analysis of $\mathrm{pmoA}$ and amoA}

To establish the clonal community composition, samples from the following depths were selected: $16.2 \mathrm{~m}$ (LKS1 clones), $16.4 \mathrm{~m}$ (LKS3 clones), $16.9 \mathrm{~m}$ (LKS8 clones), and $17.7 \mathrm{~m}$ (LKS16 clones). Since the topology of the pmoA-amoA phylogeny is in good agreement with the corresponding 16S rRNA phylogeny (Rotthauwe et al. 1997), the clone sequences from Lake Kinneret could be assigned to specific phylogenetic lineages of Alpha-, Betaand Gammaproteobacteria (Fig. 4). Gammaand Alphaproteobacteria included mainly pmoA sequences of $\mathrm{MOB}$, while Betaproteobacteria included amoA sequences of $\mathrm{AOB}$ only. The majority of clones from the chemocline of Lake Kinneret formed separated clus- 


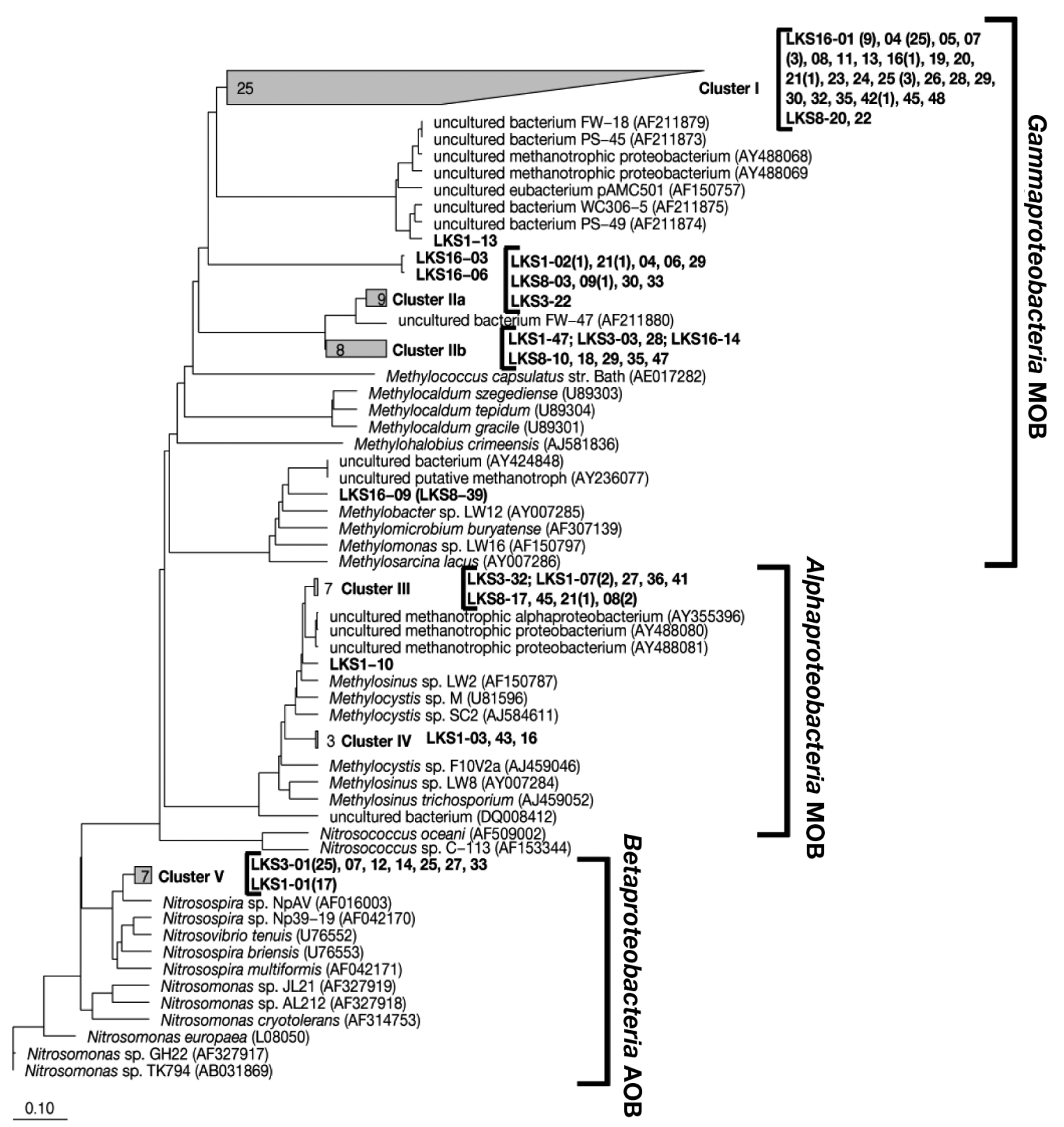

Fig. 4. Phylogenetic relationships of PmoA/AmoA inferred proteins. Evolutionary distances were determined using the neighborjoining algorithm in the software ARB. Clones from this study are marked in bold. Clones from the different depths are indicated as follows: LKS1: 16.2 m, LKS3: 16.4 m, LKS8: 16.9 m, and LKS16: $17.7 \mathrm{~m}$. All bootstrap values were over $85 \%$ and were therefore omitted from the tree

ters that did not group with sequences from cultured representatives of $\mathrm{MOB}$ or $\mathrm{AOB}$.

Within the Gammaproteobacteria lineage, which is characterized by $p m o A$ sequences from type I methanotrophs and amoA from Nitrosococcus oceani, 2 clusters with sequences from Lake Kinneret were identified. Cluster I contained the majority of sequences from $17.7 \mathrm{~m}$ (66 LKS16 clones) and 2 sequences from $16.9 \mathrm{~m}$ (LKS8-20 and -22). Cluster I was related to clonal sequences from marine and freshwater environments, in- cluding lake sediments (Costello \& Lidstrom 1999, Pester et al. 2004) and to 1 sequence from $16.2 \mathrm{~m}$ (LKS1-13). Cluster II was divided into 2 subclusters. Subcluster IIa contained 7 sequences from $16.2 \mathrm{~m}, 1$ from $16.4 \mathrm{~m}$ (LKS3-22), 5 from $16.9 \mathrm{~m}$, and 1 from an uncultured freshwater bacterium (Nold et al. 2000). Subcluster IIb contained only sequences of Lake Kinneret from 16.2, 16.4, and $16.9 \mathrm{~m}$. Two sequences, 1 from $17.7 \mathrm{~m}$ (LKS16-09) and 1 from $16.9 \mathrm{~m}$ (LKS8-39), were related to a cluster containing Methylobacter, Methy- 
lomicrobium, Methylomonas, and Methylosarcina, as well as another 2 clonal sequences from Movile Cave (Bodrossy et al. 2003, Hutchens et al. 2004).

Cluster III, within the Alphaproteobacteria lineage, included type II methanotrophs, and contained only sequences from 16.4 and $16.9 \mathrm{~m}$ of Lake Kinneret. This cluster was related to clonal sequences from sediments of Lake Constance (Bussmann et al. 2004, Pester et al. 2004), and more distantly to 1 clone from $16.2 \mathrm{~m}$ of Lake Kinneret (LKS1-10), and to Methylosinus sp. LW2 and 2 Methylocystis spp..

Cluster IV was related to methylotrophic Alphaproteobacteria (Methylosinus and Methylocystis spp.) and contained 3 sequences from $16.2 \mathrm{~m}$ (LKS1-03, -16, and $-43)$.

Only sequences from 16.2 and $16.4 \mathrm{~m}$ belonged to the Betaproteobacteria lineage, which contained exclusively amoA from AOB. They formed a single cluster (cluster V) that was closely related to amoA from Nitrosospira species. No sequences from the deepest part of the profile were observed in this group.

T-RFs were simulated for all clonal sequences obtained (Table 1). In all cases, the T-RFs predicted for the clones were observed in the sample, but because different clusters of sequences produced the same T$\mathrm{RF}$ for some of the enzymes considered, specific identification of the clones within the T-RF patterns was ambiguous.

\section{DISCUSSION}

Methanotrophic and nitrifying bacteria have an important function in many environments, due to their role in carbon, nitrogen, and oxygen cycles. In addition, they contribute to the global greenhouse effect.

Table 1. Simulation of terminal restriction fragments for the clonal sequences obtained from the samples at the metalimnion of Lake Kinneret, Israel. Fragments that could not be observed in the terminal restriction fragment length polymorphism profiles are shown in bold. Undigested fragments and fragments below $40 \mathrm{bp}$ that were not considered in the analysis are shown in italics

\begin{tabular}{|lccccc|}
\hline Cluster or clone & HaeIII & MspI & AluI & MboI & TaqI \\
\hline Cluster I & $\mathbf{8 5}, 229$ & 79 & 284 & 59 & $257, \mathbf{1 8 2}$ \\
LKS1-13 & 32 & 79 & 284 & 167 & 400 \\
LKS16-03 & 229 & 208 & 284 & 30 & 257 \\
LKS16-06 & 229 & 226 & 284 & 30 & 257 \\
Cluster IIa & 82 & 79 & 284 & 167 & 400 \\
Cluster IIb & 229 & 79,208 & $\mathbf{2 1 5}, 247$ & 30,167 & 400 \\
LKS16-09 & 531 & 531 & 94 & 531 & 531 \\
Cluster III & 45 & 244 & 393 & 30 & 439 \\
LKS1-10 & 45 & 244 & 393 & 30 & 439 \\
Cluster IV & 45 & 445 & 232 & 30 & 464 \\
Cluster V & 45 & 46 & 531 & 59 & 464 \\
\hline
\end{tabular}

This is particularly true for the methanotrophic bacteria, since methane is a potent greenhouse gas (Hanson \& Hanson 1996). It has been predicted that sediments in freshwater lakes may produce an amount equivalent to 40 to $59 \%$ of the annual global atmospheric methane flux. However, in deep stratified lakes, most of this methane never reaches the atmosphere and is consumed by methanotrophic bacteria (King 1992). Chemical analysis of the samples from the depth profile of Lake Kinneret showed that, due to anaerobic degradation of organic matter, the methane produced in the sediment and the ammonia produced in hypolimnion or sediment are distributed through the anoxic hypolimnion and are consumed at the chemocline. These data reinforce that the chemocline of Lake Kinneret is a very active oxic-anoxic interface especially for the oxidation of methane. The decrease in methane concentrations from approximately $1 \mathrm{mmol} \mathrm{l}^{-1}$ close to the sediment to $<0.1 \mu \mathrm{mol} \mathrm{l^{-1 }}$ above the oxycline suggests a high metabolic activity of the methane-oxidizing communities in this layer.

The finding that the maximum of methanotrophic activity in Lake Kinneret occurred where oxygen concentrations were below the detection limit is in agreement with recent results from littoral and profundal sites in Lake Constance (Rahalkar et al. 2009). Similarly, in the Black Sea water column, aerobic methanotrophs and methane oxidation were recorded at water depths in which oxygen concentration was below the detection limit (Schubert et al. 2006). It is still unclear whether methanotrophs are responsible for the methane oxidation under these conditions (Schubert et al. 2006, Rahalkar et al. 2009), since they require oxygen as an electron acceptor. It has been postulated that MOB can also be responsible for methane oxidation under anaerobic conditions (Rahalkar et al. 2009), probably by using an alternative terminal electron acceptor like nitrate. In the case of Lake Kinneret, it is still possible that internal seiche tilting of the chemocline, shear flow, and turbulence contribute to mixing and displacement of water layers within the metalimnion, allowing oxygen to reach the methane at the lower part of the chemocline. When both coexist even at low concentrations, methane oxidation can take place.

The grouping of T-RFLP profiles of pmoA by MDS analyses follows the concentration gradient and the oxidation rate profile of methane. Communities from the deepest layers, characterized by higher methane oxidation rates, were separated from those in 
the upper part of the profile. Clonal pmoA sequences from cluster I appear to dominate the lower part of the gradient, and are especially interesting because they seem to represent a group of thus far uncultured MOB with the ability to oxidize methane very efficiently at low oxygen concentrations.

We observed a more common occurrence of type I methanotrophs (grouped into the Gammaproteobacteria lineage) in our clone libraries. Results obtained for methanotrophic bacteria in profundal sediments of Lake Washington (Costello \& Lidstrom 1999) and Lake Constance (Pester et al. 2004) also suggest the dominance of type I MOB in these freshwater environments. Sequences related to type II MOB and betaproteobacterial AOB were also detected in this study. Type II MOB sequences from Lake Kinneret were grouped with those from sediments of Lake Constance (Pester et al. 2004), and in both lakes they seem to represent a small fraction of the MOB communities compared to type I MOB. However, it should be noted that due to the elevated number of amplification cycles, there is a possibility for the saturation of certain groups of sequences after PCR, and thus a quantitative interpretation of the results should be made with caution.

The amoA sequences observed in our study were related to Nitrosospira sp. NpAV. Sequences of amoA were restricted to the upper part of the depth profile, although a decrease in $\mathrm{NH}_{4}{ }^{+}$concentration was recorded all over it. Because nitrate was present just in this upper part of the gradient, this supports the conclusion that consumption of ammonia in this zone at this time is at least partially due to ammonia oxidation by AOB. Unfortunately, data for ammonia oxidation rates in the same samples are not available. However, ${ }^{14} \mathrm{C}$ bicarbonate uptake experiments that have been carried out for many years and in different seasons suggest that at the chemocline in autumn, when the oxycline and the thermocline are at the same depth within a narrow metalimnetic layer below the euphotic zone, sulfide oxidation is a much more significant process than ammonia oxidation (Hadas et al. 2001). Although ammonia oxidation exists, and may be coupled to denitrification, as shown by amplification of the nitrite reductase gene nirS in the same samples (Junier et al. 2008c), it is negligible during this period. In the lower part of the gradient, ammonia concentrations decrease from $14.2 \mu \mathrm{mol} \mathrm{l}^{-1}$ at $17.7 \mathrm{~m}$ to $6.3 \mu \mathrm{mol} \mathrm{l^{-1 }}$ at $16.6 \mathrm{~m}$ depth, without the accumulation of nitrate and in the absence of $a m o A$ sequences in the libraries suggesting assimilation processes by metalimnetic biota rather than ammonia oxidation.

The ability of methanotrophic bacteria to oxidize ammonia and of ammonia oxidizers to oxidize methane, although displaying higher affinity for their respective substrate, led to the hypothesis that both groups might be acting together or excluding each other depending on the environmental conditions (Hanson \& Hanson 1996). According to this hypothesis, it is not impossible that MOB might be responsible for the oxidation of ammonia in the deeper part of the chemocline of Lake Kinneret where ammonia-oxidizing bacteria are apparently absent. Further experimentation is needed to test these hypotheses.

Previous studies have found biases towards the preferential amplification of amoA sequences (Bourne et al. 2001, Erwin et al. 2005) when the primers A189A682 (Holmes et al. 1995) were used to analyze MOB communities. The in silico analysis of the primers with sequences from cultured $\mathrm{AOB}$ and $\mathrm{MOB}$ suggest that especially the reverse primer (A682) matches with higher affinity sequences related to Nitrosospira clusters 0 and 1 (Junier et al. 2008b). Hence, these primers have been deemed as inadequate to study MOB communities (Bourne et al. 2001). However, the results obtained in Lake Kinneret do not support this, since a higher frequency of $p m o A$ sequences (corresponding to type I and II MOB) was detected in all clone libraries except that from $16.2 \mathrm{~m}$, in which amo $A$ sequences were more frequent.

This study provides new information regarding the community composition of $\mathrm{MOB}$ and $\mathrm{AOB}$ in the chemocline of Lake Kinneret. Although the type of analyses carried out here cannot provide information on the activity and abundance in situ of MOB and AOB, it constitutes the basis for assessing the relative importance of the specific groups and the effect of the sharp chemical gradients on the shaping of the MOB and AOB communities in the chemocline of Lake Kinneret.

Acknowledgements. This research was supported by the German-Israeli Foundation (grant no. I-711-83.8/2001) and the Binational Science Foundation (grant no. 2002-206). Samples were taken during the German Israeli Minerva School in October 2004. We thank the Yigal Allon Kinneret Limnological Laboratory personnel for their assistance during the sampling and T. Junier for help with the statistical analysis.

\section{LITERATURE CITED}

APHA (American Public Health Association) (2001) Standard methods for the examination of water and waste water, 20th edn. American Public Health Association, Washington, DC

Bodrossy L, Stralis-Pavese N, Murrell JC, Radajewski S, Weilharter A, Sessitsch A (2003) Development and validation of a diagnostic microbial microarray for methanotrophs. Environ Microbiol 5:566-582

Bourne DG, McDonald IR, Murrell JC (2001) Comparison of $p m o A$ PCR primer sets as tools for investigating methanotroph diversity in three Danish soils. Appl Environ Microbiol 67:3802-3809

Brune A, Frenzel P, Cypionka H (2000) Life at the oxic-anoxic interface: microbial activities and adaptations. FEMS Microbiol Rev 24:691-710 
Bussmann I, Pester M, Brune A, Schink B (2004) Preferential cultivation of type II methanotrophic bacteria from littoral sediments (Lake Constance). FEMS Microbiol Ecol 47:179-189

Clarke KR (1993) Non-parametric multivariate analyses of changes in community structure. Aust J Ecol 18:117-143

- Costello AM, Lidstrom ME (1999) Molecular characterization of functional and phylogenetic genes from natural populations of methanotrophs in lake sediments. Appl Environ Microbiol 65:5066-5074

Eckert W, Conrad R (2007) Sulfide and methane evolution in the hypolimnion of a subtropical lake: a three year study. Biogeochemistry 82:67-76

Eckert W, Imberger J, Saggio A (2002) Biogeochemical response to physical forcing in the water column of a warm monomictic lake. Biogeochemistry 61:291-307

Erwin DP, Erickson IK, Delwiche ME, Colwell FS, Strap JL, Crawford RL (2005) Diversity of oxygenase genes from methane- and ammonia-oxidizing bacteria in the Eastern Snake River Plain Aquifer. Appl Environ Microbiol 71: 2016-2025

Hadas O, Pinkas R, Erez J (2001) High chemoautotrophic primary production in Lake Kinneret, Israel: a neglected link in the carbon cycle of the lake. Limnol Oceanogr 46: 1968-1976

Hanson RS, Hanson TE (1996) Methanotrophic bacteria. Microbiol Rev 60:439-472

Holmes AJ, Costello A, Lidstrom ME, Murrell JC (1995) Evidence that particulate methane monooxygenase and ammonia monooxygenase may be evolutionarily related. FEMS Microbiol Lett 132:203-208

Hutchens E, Radajewski S, Dumont MG, McDonald IR, Murrell JC (2004) Analysis of methanotrophic bacteria in Movile Cave by stable isotope probing. Environ Microbiol 6:111-120

> Junier P, Junier T, Witzel KP (2008a) TRiFLe, a program for in silico terminal restriction fragment length polymorphism analysis with user-defined sequence sets. Appl Environ Microbiol 74:6452-6456

Junier P, Kim OS, Molina V, Limburg P, Junier T, Imhoff JF, Witzel KP (2008b) Comparative in silico analysis of PCR primers suited for diagnostics and cloning of ammonia

Editorial responsibility: Patricia Glibert, Cambridge, Maryland, USA monooxygenase genes from ammonia-oxidizing bacteria. FEMS Microbiol Ecol 64:141-152

Junier P, Kim OS, Witzel KP, Imhoff JF, Hadas O (2008c) Habitat partitioning of denitrifying bacterial communities carrying nirS or nirK genes in the stratified water column of Lake Kinneret, Israel. Aquat Microb Ecol 51:129-140

- Kim OS, Junier P, Imhoff JF, Witzel KP (2006) Comparative analysis of ammonia-oxidizing bacterial communities in two lakes in North Germany and the Baltic Sea. Arch Hydrobiol 167:335-350

King GM (1992) Ecological aspects of methane oxidation, a key determinant of global methane dynamics. In: Marshall KC (ed) Advances in microbial ecology. Plenum Press, New York, p 431-474

Nold SC, Zhou J, Devol AH, Tiedje JM (2000) Pacific Northwest marine sediments contain ammonia-oxidizing bacteria in the $\beta$ subdivision of the Proteobacteria. Appl Environ Microbiol 66:4532-4535

Pester M, Friedrich MW, Schink B, Brune A (2004) pmoAbased analysis of methanotrophs in a littoral lake sediment reveals a diverse and stable community in a dynamic environment. Appl Environ Microbiol 70:3138-3142

> Prosser JI (1990) Autotrophic nitrification in bacteria. Adv Microb Physiol 30:125-181

> Rahalkar M, Deutzmann J, Schink B, Bussmann I (2009) Abundance and activity of methanotrophic bacteria in littoral and profundal sediments of Lake Constance (Germany). Appl Environ Microbiol 75:119-126

Rotthauwe JH, Witzel KP, Liesack W (1997) The ammonia monooxygenase structural gene $a m o A$ as a functional marker: molecular fine-scale analysis of natural ammoniaoxidizing populations. Appl Environ Microbiol 63: $4704-4712$

Schmidt U, Conrad R (1993) Hydrogen, carbon monoxide, and methane dynamics in Lake Constance. Limnol Oceanogr 38:1214-1226

Schubert CJ, Coolen MJ, Neretin LN, Schippers A and others (2006) Aerobic and anaerobic methanotrophs in the Black Sea water column. Environ Microbiol 8:1844-1856

Semrau JD, Chistoserdov A, Lebron J, Costello A and others (1995) Particulate methane monooxygenase genes in methanotrophs. J Bacteriol 177:3071-3077

Submitted: April 16, 2009; Accepted: September 4, 2009 Proofs received from author(s): December 16, 2009 